Article

\title{
Does Religiosity Affect Attitudes toward the Ethics of Tax Evasion? The Case of Turkey
}

\author{
Robert W. McGee ${ }^{1}$, Serkan Benk ${ }^{2, *}$, Bahadır Yüzbaş1 ${ }^{3}$ (I) and Tamer Budak ${ }^{4}$ (I) \\ 1 Department of Accounting, Finance, Health Administration, and Information Systems, Broadwell College of \\ Business and Economics, Fayetteville State University, Fayetteville, NC 28301, USA; rmcgee3@uncfsu.edu \\ 2 Department of Public Finance, Faculty of Economics and Administrative Sciences, İnönü University, \\ 44280 Battalgazi, Malatya, Turkey \\ 3 Department of Econometrics, Faculty of Economics and Administrative Sciences, İnönü University, \\ 44280 Battalgazi, Malatya, Turkey; bahadir.yuzbasi@inonu.edu.tr \\ 4 Department of International Trade, Faculty of Economics and Administrative Sciences, Alanya Alaaddin \\ Keykubat University, 07400 Alanya, Antalya, Turkey; tamer.budak@alanya.edu.tr \\ * Correspondence: serkan.benk@inonu.edu.tr
}

Received: 23 June 2020; Accepted: 14 September 2020; Published: 18 September 2020

check for updates

\begin{abstract}
This study surveys the opinion of a wide segment of Turkish society on the ethics of tax evasion. The survey instrument includes 18 statements used to justify tax evasion in the past. The research also finds that some reasons to justify tax evasion proved more attractive to participants than others. In our survey, the strongest support for tax evasion was in cases where the government abused human rights, where the government was corrupt or wasted tax funds, or where the taxpayer did not benefit from the tax expenditures. Conversely, the weakest arguments were in cases where the taxpayer did benefit from the tax expenditures or where the tax funds were spent wisely. What separates this study from others on the ethics of tax evasion is that it addresses interpersonal and intrapersonal religiosity. Its finding confirms the existence of an important relationship between both interpersonal and intrapersonal religiosity and the view toward the ethics of tax evasion.
\end{abstract}

Keywords: tax evasion; ethics; religiosity; intrapersonal religiosity; interpersonal religiosity

\section{Introduction}

More than 100 articles and book chapters have been published on the ethics of tax evasion in recent decades. Some are theoretical, while others are empirical in nature. The current study aims to do both. A few studies have examined the religious aspects of ethics and taxation. Of those studies, the vast majority have compared the views of various religions on the subject of tax evasion. The current study reviews some of prior studies, but it also examines an aspect of tax evasion that has been relatively neglected in the literature-religiosity.

The literature on the ethics of tax evasion is reviewed in Part 2. Part 3 discusses the methodology, which consists of a survey instrument that was distributed to a wide range of participants in Turkey. The survey included some traditional questions as well as a series of questions on religiosity, which is from past studies. The results of the study are presented in Part 4. Finally, Part 5 presents conclusions and suggestions for further research.

\section{Literature Review}

Many research studies have been done on tax evasion over the past few decades (Collymore 2020a). One of the earliest, best, and most comprehensive theoretical studies was done by Crowe (1944), a Catholic priest who wrote a doctoral dissertation on the ethical duty of paying just taxes. 
He examined 500 years of religious and philosophical writings on tax evasion; most of them were written in Latin. Thus, he offered the English-speaking world an opportunity to explore formerly unknown literature.

The Bible (Matthew 22:17, 21; Romans 13:1-2) supported the view that individuals had a moral duty to pay taxes to the secular authority (Schansberg 1998). Some Catholic and other Christian scholars made an exception for rulers who were corrupt (Crowe 1944). Other scholars made exceptions in cases where there was an inability to pay (LeCard 1869; Morales 1998) or where the tax burden was too high (Crowe 1944; McGee 2012a). Some other scholars held the view that there was little or no duty task to pay taxes (Spooner 1870; Block and Torsell 2020). More recent scholarship has applied just war theory to tax evasion and held that there may be an ethical duty not to support an unjust war (Pennock 1998).

The Christian literature on tax evasion is diverse. At one extreme is the Mormon view, which holds that tax evasion can never be justified. A review of the Mormon literature did not find a single exception that would justify tax evasion (Smith and Kimball 1998). However, a study of Mormon university students showed that they were more flexible on the topic, justifying tax evasion in several cases (McGee and Smith 2007), in particular in cases where the government takes part in human rights abuses, but also in other cases, such as where the government is corrupt or where the tax funds are wasted.

Most of the Christian literature would permit tax evasion in certain situations, most notably where the government is corrupt, where there is an inability to pay, or when tax rates are excessively high (McGee 2012a, pp. 201-10; McGee and Benk 2019). Some Christian literature takes a classic liberal approach (Gronbacher 1998).

The literature of the Baha'i religion is nearly as strict as that of the Mormons, holding that tax evasion can only be justified when the government oppresses members of the Baha'i faith. (DeMoville 1998). They believe that they have an ethical duty to pay taxes, even to Hitler, as long as he does not persecute members of their faith.

The Jewish literature is highly opposed to tax evasion, at least the majority of the time. There are mainly three reasons for this strong aversion to tax evasion. There is a strain of opinion in the Jewish literature that one must never do anything to disparage another Jew. A second reason not to evade taxes is that doing so might cause one to go to prison, making it difficult or impossible to perform mitzvot (good works). The third reason might be summarized as "the law is the law" (Cohn 1998, 2012; Tamari 1998), which means that there is always a duty to obey every law.

All three of these views are open to criticism. It could be argued that there is no moral duty to behave in a certain manner just so that some segment of the general public will not look down on other members of a religious or ethnic group. An extreme case would be that the Jews have a moral duty to pay taxes, even to the likes of Hitler, so that other Jews in the community will not be viewed as tax evaders.

The view that paying taxes is required in order that they will not be prevented from performing good deeds also falls apart upon analysis. It might actually be possible to do more good deeds in a jail, where prisoners are compelled to act so in repentance.

The claim that "the law is the law" also does not hold up to analysis. The example of Hitler given above may be used again to show the weakness of this position. Martin King (1963) and others (Thoreau 1849) have argued that there is a moral duty to defy bad laws.

Relevant also is the confrontation "if you don't like it, leave it". It is very popular in the United States at the moment, not so much for tax evasion, but for individuals who strongly dislike whoever the current president is. This hostility is not necessarily Jewish or Christian in nature but a secular one. The problem with such a strong discontent is that individuals who leave one regime because they do not like the tax system simply enter into another regime and a new tax system that they may not like, either. For those who feel that all taxation is nothing short of theft (because it involves the confiscation of a portion of the fruits of one's labor), the "if you don't like it, leave" stance is akin to telling a slave that if you do not like your current slave master, you can go to work for one you like better. 
The Islamic literature is seemingly at both ends of the spectrum, at least on the surface (McGee Robert 2012b). On one end, two Muslim scholars have the opinion that there is no moral obligation to pay taxes that are based on income or that cause prices to rise. Thus, there is no moral duty to pay income taxes, sales taxes, or tariffs, which are another form of taxation (Ahmad 1995; Yusuf 1971).

At the other end of the spectrum, another Muslim scholar interprets the Muslim literature to state that tax evasion is never justified, but only in situations where the government is run by Sharia law, because evading taxes in such a case would be stealing from Allah (Jalili 2012). However, this scholar avoided discussing whether tax evasion would be unethical in a country that is not run by Sharia law.

In recent years, there have been several empirical papers on the ethics of tax evasion. One set of studies involved the distribution of an 18-statement survey to various groups. Each statement began, "Tax evasion would be ethical if ... ". The sentences ended with a variety of reasons that have been given in the past to justify tax evasion. Many of the questions used in these surveys were based on the issues that Crowe (1944) uncovered in his examination of Christian literature on the subject. McGee (2012a) added three questions dealing with various human rights abuses.

In general, these studies found that some opinions to justify tax evasion were more robust than others, and that there was a cognizable support for tax evasion, but then, that opposition to evasion was usually quite strong. The instances where tax evasion was most strongly justified were in cases where the government was involved in human rights abuses, where the government was corrupt, where tax rates were too high, or where there was an inability to pay. Tax evasion was found to be more justifiable in cases where the taxpayer did not receive much in exchange for the tax payments, and was less justifiable in cases where taxpayers received substantial benefits, or where the government spent tax funds efficiently (Kandri and Mamuti 2019; Collymore 2020b). Many of these studies are summarized in McGee (2012a).

Several studies over the years have found that evasion increases as tax rates increase (Alm et al. 1992; Slemrod 1985), which makes sense because the risk-reward ratio increases. Another study found that tax evasion decreases as audits increase (Cebula and Saadatmand 2005).

Demographic variables were sometimes examined to determine whether certain groups had varying opinions. In most studies, women were either significantly more opposed to tax evasion than men (Collymore 2020b; McGee and Guo 2007; McGee et al. 2008), or both genders were equally opposed to tax evasion (McGee et al. 2012b). In some cases, men were found to be significantly more opposed to tax evasion (McGee et al. 2011). The studies that examined age demography generally found that young people were less opposed to tax evasion than older people (McGee 2012a, pp. 441-49). Level of education sometimes was correlated to acceptance of tax evasion, but the various studies conducted over the years have reached different conclusions. In some cases, the more education a person had, the higher the aversion to tax evasion, but in other cases, the relationship was just the opposite (McGee 2012a, pp. 451-57).

Another group of studies used World Values Survey data to discover the extent of support for tax evasion. The World Values Surveys involved asking thousands of people in dozens of countries questions on a wide range of subjects. One question was related to whether it would be justified to cheat on taxes if you could. Respondents were asked to pick a number from 1 to 7 to signify the extent of their agreement or disagreement with the statement.

These studies generally unveiled that there was fairly strong opposition to tax evasion, although the extent varied by country. People in the former Soviet Union countries or Soviet satellite countries tended to be less opposed to tax evasion than people in western European countries or the United States (Alm et al. 2006; McGee and Maranjyan 2008; McGee et al. 2008, 2012a; McGee 2012a). Demographic differences were also found. Although women were often more opposed to tax evasion, the difference in mean scores was not always significant. Older people tended to be more opposed to tax evasion than younger people. Views toward tax evasion were regional, in the sense that opposition was stronger in some geographic locations than others (Alm and Torgler 2006; Alm et al. 2006; Alm and Martinez-Vazquez 2010; McGee 2012a; Torgler 2012). 
Benk et al. (2009) surveyed Turkish business students on six ethical topics that were covered in the World Values Surveys. They concluded that paying cash to avoid paying a sales/VAT tax was substantially more attractive than cheating on taxes if you have a chance. Women were generally more opposed to evading sales/VAT taxes by paying cash than were men.

Various studies have examined the question: How serious is tax evasion compared to other crimes? The general finding in these studies was that tax evasion is not as serious as many other crimes on the list, which might lead one to wonder why tax evasion is treated so harshly in some countries (Gupta 2009; Burton et al. 2005; Karlinsky et al. 2004; Benk et al. 2009; Aljaaidi et al. 2011; Gupta and McGee 2010; James et al. 2019; Mamuti et al. 2019).

A few studies have been undertaken from the perspective of religiosity (Torgler 2007, 2012; McGee 2012a, pp. 459-69; Benk et al. 2015). The general findings of these studies were that people who were more religious tended to be more opposed to tax evasion than those who were less religious. Studies have also pointed to a negative correlation between religiosity and crime in general (Lipford et al. 1993; Hull 2000; Anderson and Tollison 1992; Hull and Bold 1989).

\section{Methodology}

\subsection{Participants}

Participants were randomly selected from individual taxpayers in Malatya, a city in Turkey. Out of a total of 500 questionnaire forms distributed to taxpayers, 378 usable responses were obtained. The return rate was 75.60 percent. During the analysis, only 4 questionnaire forms were omitted as invalid. Refer to Table 1 for details.

A majority of the respondents ( 36.90 percent) had a graduate degree followed by 34.20 percent with a high school diploma. The sample comprised 67.10 percent of males and 32.40 percent females. The sample was separated into three age groups: (1) 18 to 24 (7.50 percent); (2) 25 to 44 (70.30 percent); (3) 45 and above (21.70 percent). Table 1 also indicates 66.00 percent of the respondents were married, while the rest (32.90 percent) were single.

Table 1. Demographics.

\begin{tabular}{lcc}
\hline \multicolumn{1}{c}{ Respondents } & Sample Size (374) & Percentage (\%) \\
\hline Education & 76 & 20.30 \\
\hline Less than high school & 128 & 34.20 \\
High school & 23 & 6.10 \\
Vocational school & 138 & 36.90 \\
Graduate & 9 & 2.40 \\
Postgraduate & 0 & 0.00 \\
Missing & & \\
\hline Gender & 251 & 67.10 \\
\hline Male & 121 & 32.40 \\
Female & 2 & 0.50 \\
Missing & & \\
\hline Marital Status & 247 & 66.00 \\
\hline Married & 123 & 32.90 \\
Single & 4 & 1.10 \\
Missing & & 7.50 \\
\hline Age & 28 & 70.30 \\
\hline 18-24 & 263 & 21.70 \\
25-44 & 81 & 0.50 \\
Missing & 2 & \\
\hline
\end{tabular}




\subsection{Measures}

The survey instrument was divided into three parts. The first section included demographic information, such as gender, age, marital status, and level of education. The religiosity scale was placed in the second part. The last part of the survey included the ethics of tax evasion statements.

In this paper, religiosity was measured on the bases of "The Religious Commitment Inventory-10" (now referred to as RCI-10) (Worthington et al. 2003) (5-point Likert scale; $1=$ not at all true for me, $5=$ totally true to me). RCI-10 was divided into two subscales, namely, intrapersonal (six items; RCI-1, RCI-2, RCI-3, RCI-4, RCI-5, and RCI-6) and interpersonal (four items; RCI-7, RCI-8, RCI-9, and RCI-10). The intrapersonal subscale measures the strength of a person's faith and the extent of involvement of religion into his or her personal life. On the other side, the interpersonal subscale evaluates participation in organized religious activities, which means a person's association with religious organizations and working for organizing and supporting their activities (Goel and Misra 2020). RCI-10 also enables us to measure the level of individual religiosity. According to the scale, an individual with a score of 38 or higher would be classified as highly religious (Worthington et al. 2003, p. 94). Therefore, a low level of religiosity was in the range of 0 to 37 and a high level of religiosity was between 38 and 50 (Mohd Ali 2013).

The 18-item ethics of tax evasion questionnaire was used to rate attitudes towards tax evasion. The first 15 statements reflected the major arguments that have been used in the literature for the past 500 years to justify tax evasion (Crowe 1944). The last three statements were added so that more recent human rights issues could be incorporated into the survey (McGee 2012a). By using a five-point Likert scale, respondents were asked to put the most appropriate number in the designated space to indicate the extent of their agreement or disagreement with each statement $(1=$ strongly agree; $5=$ strongly disagree).

\subsection{Analysis}

The framework for the research is illustrated in Figure 1. Based on the framework, this paper investigates whether religiosity affects behaviors toward the ethics of tax evasion. For this reason, in this study, the dependent variable was represented by ethics of tax evasion and the independent variable was religiosity.

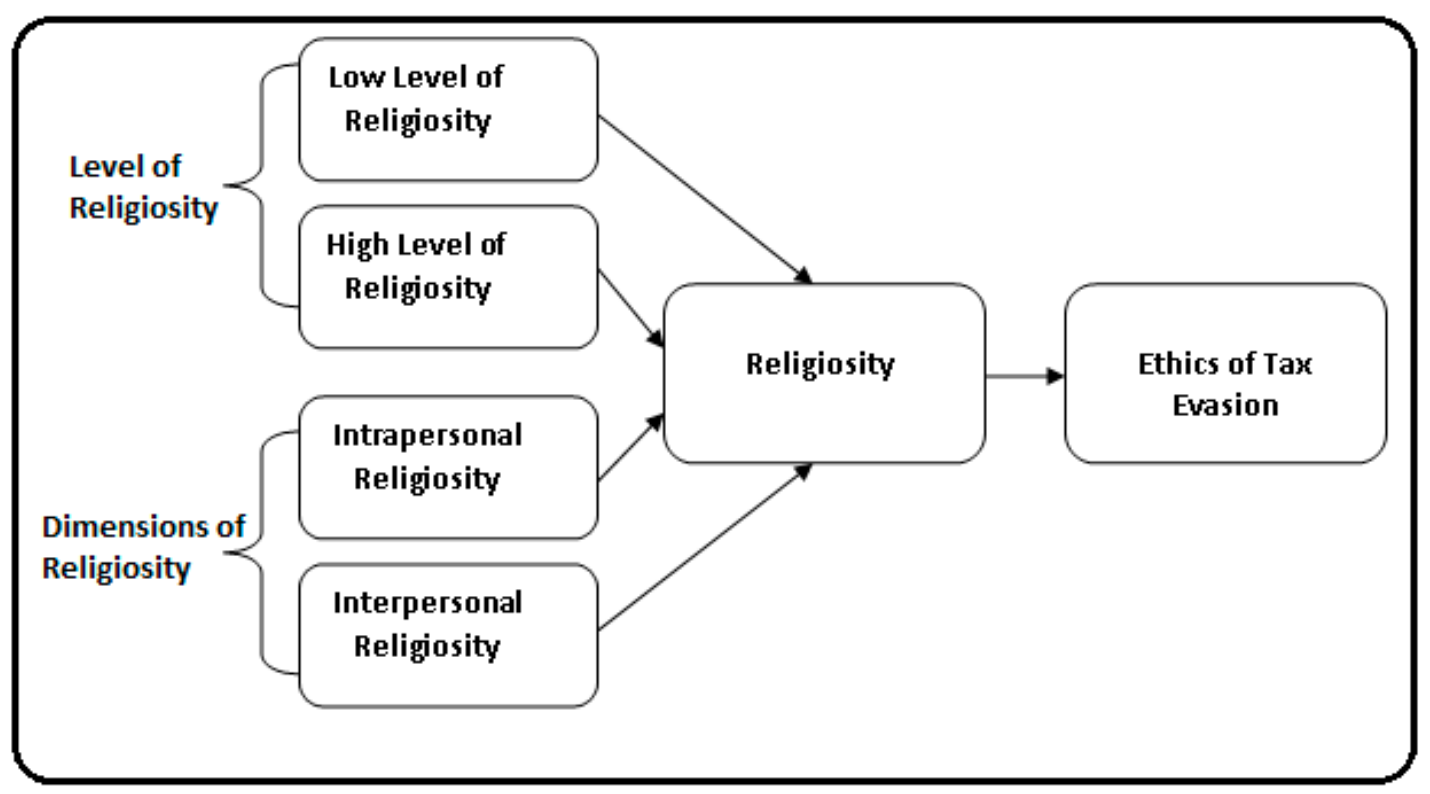

Figure 1. Research framework for the study. 
As mentioned earlier, RCI-10 gives us the opportunity to observe both levels and subdimensions of religiosity. So firstly, simple linear regression models were used to determine the influence of the level of religiosity on the response variable ethics of tax evasion. This was done separately for a low level of religiosity and a high level of religiosity. Finally, the independent variable religiosity was subdivided into two parts as follows: interpersonal and intrapersonal religiosity, and their relationship to their views on the ethics of tax evasion. To test the impact of dimensions of religiosity on the ethics of tax evasion, factor analysis and multiple linear regression models were used.

\section{Results}

\subsection{Preliminary Results}

Table 2 shows each statement for RCI-10. This scale has been also divided into a subscale for displaying items under intrapersonal religiosity and interpersonal religiosity. RCI 3 ("It is important to me to spend periods of time in private religious thought and reflection"), which is the item of intrapersonal religiosity that received the highest mean score of 4.09 , followed by RCI 5 ("Religion is especially important to me because it answers many questions about the meaning of life") and RCI 1 ("My religious beliefs lie behind my whole approach to life"), which are the items of intrapersonal religiosity.

Table 2. The Religious Commitment Inventory-10 (RCI-10).

\begin{tabular}{|c|c|c|c|c|}
\hline Code & Statement & $\mathbf{N}$ & Mean & SD \\
\hline RCI 1 & $\begin{array}{l}\text { "My religious beliefs lie behind my whole approach to life." } \\
\text { (Intrapersonal Religiosity) }\end{array}$ & 373 & 3.80 & 1.100 \\
\hline RCI 2 & $\begin{array}{l}\text { "I spend time trying to grow in understanding of my faith." } \\
\text { (Intrapersonal Religiosity) }\end{array}$ & 373 & 3.92 & 0.987 \\
\hline RCI 3 & $\begin{array}{l}\text { "It is important to me to spend periods of time in private religious } \\
\text { thought and reflection." (Intrapersonal Religiosity) }\end{array}$ & 373 & 4.09 & 0.977 \\
\hline RCI 4 & $\begin{array}{l}\text { "Religious beliefs influence all my dealings in life." } \\
\text { (Intrapersonal Religiosity) }\end{array}$ & 373 & 3.65 & 1.185 \\
\hline RCI 5 & $\begin{array}{l}\text { "Religion is especially important to me because it answers many } \\
\text { questions about the meaning" (Intrapersonal Religiosity) }\end{array}$ & 371 & 3.90 & 1.019 \\
\hline RCI 6 & $\begin{array}{l}\text { "I often read books and magazines about my faith." } \\
\text { (Intrapersonal Religiosity) }\end{array}$ & 368 & 3.14 & 1.087 \\
\hline RCI 7 & $\begin{array}{l}\text { "I keep well informed about my local religious group and have } \\
\text { some influence in its decisions." (Interpersonal Religiosity) }\end{array}$ & 372 & 2.63 & 1.099 \\
\hline RCI 8 & $\begin{array}{l}\text { "I enjoy spending time with others of my religious affiliation." } \\
\text { (Interpersonal Religiosity) }\end{array}$ & 373 & 3.06 & 1.194 \\
\hline RCI 9 & $\begin{array}{l}\text { "I enjoy working in the activities of my religious organization." } \\
\text { (Interpersonal Religiosity) }\end{array}$ & 372 & 2.68 & 1.178 \\
\hline RCI 10 & $\begin{array}{l}\text { "I make financial contributions to my religious organization." } \\
\text { (Interpersonal Religiosity) }\end{array}$ & 372 & 1.90 & 1.030 \\
\hline
\end{tabular}

$1=$ not at all true for me $5=$ totally true to me; Cronbach's alpha $=0.906$.

Table 3 shows the descriptive statistics for each of the 18 expressions of the ethics of tax evasion. The mean score is 3.90, serious opposition to tax evasion. E 7 ("Tax evasion is ethical even if a large portion of the money collected is spent on worthy projects") received the highest mean score of 4.41 followed by E 5 ("Tax evasion is ethical even if most of the money collected is spent wisely", mean = 4.40) and E 9 ("Tax evasion is ethical even if a large portion of the money collected is spent on projects that do benefit me", mean =4.36). E 17 ("Tax evasion is ethical if the government discriminates against me because of my religion, race or ethnic background") received the lowest mean score of 
2.88. Thus, the results demonstrate that some reasons for evading taxes were more strongly supported than others.

Table 3. Ethics of tax evasion-18 statements.

\begin{tabular}{|c|c|c|c|c|}
\hline Code & Statement & $\mathbf{N}$ & Mean & SD \\
\hline E 1 & "Tax evasion is ethical if tax rates are too high." & 372 & 4.03 & 0.997 \\
\hline E 2 & $\begin{array}{l}\text { "Tax evasion is ethical even if tax rates are not too high because the } \\
\text { government is not entitled to take as much as it is taking from me." }\end{array}$ & 371 & 4.33 & 0.789 \\
\hline E 3 & "Tax evasion is ethical if the tax system is unfair." & 373 & 3.94 & 1.040 \\
\hline E 4 & "Tax evasion is ethical if a large portion of the money collected is wasted." & 372 & 3.91 & 1.106 \\
\hline E 5 & "Tax evasion is ethical even if most of the money collected is spent wisely." & 370 & 4.40 & 0.751 \\
\hline E 6 & $\begin{array}{l}\text { "Tax evasion is ethical if a large portion of the money collected is spent on } \\
\text { projects that I morally disapprove of." }\end{array}$ & 371 & 3.96 & 0.995 \\
\hline E 7 & $\begin{array}{l}\text { "Tax evasion is ethical even if a large portion of the money collected is } \\
\text { spent on worthy projects." }\end{array}$ & 373 & 4.41 & 0.701 \\
\hline E 8 & $\begin{array}{l}\text { "Tax evasion is ethical if a large portion of the money collected is spent on } \\
\text { projects that do not benefit me." }\end{array}$ & 373 & 4.15 & 0.893 \\
\hline E 9 & $\begin{array}{l}\text { "Tax evasion is ethical even if a large portion of the money collected is } \\
\text { spent on projects that do benefit me." }\end{array}$ & 371 & 4.36 & 0.767 \\
\hline E 10 & "Tax evasion is ethical if everyone is doing it." & 373 & 4.06 & 1.033 \\
\hline E 11 & $\begin{array}{l}\text { "Tax evasion is ethical if a significant portion of the money collected winds } \\
\text { up in the pockets of corrupt politicians or their families and friends." }\end{array}$ & 372 & 3.28 & 1.271 \\
\hline E 12 & "Tax evasion is ethical if the probability of getting caught is low" & 372 & 4.18 & 0.843 \\
\hline E 13 & $\begin{array}{l}\text { "Tax evasion is ethical if some of the proceeds go to support a war that I } \\
\text { consider to be unjust." }\end{array}$ & 372 & 3.65 & 1.081 \\
\hline E 14 & "Tax evasion is ethical if I can't afford to pay." & 373 & 3.98 & 1.015 \\
\hline E 15 & $\begin{array}{l}\text { "Tax evasion is ethical even if it means that if I pay less, others will have to } \\
\text { pay more." }\end{array}$ & 372 & 4.33 & 0.744 \\
\hline E 16 & $\begin{array}{l}\text { "Tax evasion would be ethical if I lived under an oppressive regime like } \\
\text { Nazi Germany or Stalinist Russia." }\end{array}$ & 373 & 3.38 & 1.236 \\
\hline E 17 & $\begin{array}{l}\text { "Tax evasion is ethical if the government discriminates against me because } \\
\text { of my religion, race or ethnic background." }\end{array}$ & 373 & 2.88 & 1.217 \\
\hline \multirow[t]{2}{*}{ E 18} & $\begin{array}{l}\text { "Tax evasion is ethical if the government imprisons people for their } \\
\text { political opinions." }\end{array}$ & 372 & 2.98 & 1.226 \\
\hline & Average Score & 373 & 3.90 & 1.099 \\
\hline
\end{tabular}

\subsection{Level of Religiosity and Ethics of Tax Evasion}

The analysis of simple linear regression was applied to analyze the impact of the level of religiosity (Model 1 is low level of religiosity, Model 2 is high level of religiosity) on the ethics of tax evasion (see Table 4). The regression analysis in Model 1 produced an adjusted $R^{2}=0.029, F(1,269)=9.145$, $p=0.002$ and Model 2 produced an adjusted $R^{2}=0.002, F(1,101)=1.241, p=0.268$ (see Table 5).

Regarding the level of religiosity, it seems that people who have a low level of religiosity (Model 1) tended to report a higher score in the ethics of tax evasion. In this research, a high level of religiosity (Model 2) is an insignificant predictor for behaviors toward the ethics of tax evasion. 
Table 4. Regression Analysis of Model 1.

\begin{tabular}{|c|c|c|c|}
\hline \multirow[t]{2}{*}{ Independent Variable } & \multicolumn{3}{|c|}{ Dependent Variable: Ethics of Tax Evasion } \\
\hline & $\beta$ & $t$-Value & Sig. \\
\hline Intercept & 2.740 & 14.046 & $0.000 * * *$ \\
\hline \multirow[t]{5}{*}{ Low level of religiosity } & -0.020 & -3.024 & $0.003 * *$ \\
\hline & & 33, Adj. $R^{2}$ & \\
\hline & & $=9.145, p$ & \\
\hline & & hoscedast & \\
\hline & & test $=0.2$ & \\
\hline
\end{tabular}

Table 5. Regression Analysis of Model 2.

\begin{tabular}{cccc}
\hline Independent Variable & & Dependent Variable: Ethics of Tax Evasion & \\
\hline & $\boldsymbol{\beta}$ & $\boldsymbol{t}$-Value & Sig. \\
\hline Intercept & 1.009 & 1.239 & 0.218 \\
High level of religiosity & 0.022 & 1.114 & 0.268 \\
& & $R^{2}=0.012$, Adj. $R^{2}=0.002$ & \\
& $F(1,100)=1.241, p=0.268$ \\
& Homoscedasticity \\
& Breusch-Pagan test $=10.20, p=0.001{ }^{* *}$ \\
\hline
\end{tabular}

\subsection{Dimensions of Religiosity and the Ethics of Tax Evasion}

To determine subdimensions of the RCI-10, exploratory factor analysis was applied. Before the use of factor analysis, Kaiser-Meyer-Olkin analysis to check whether the sample was incongruent displayed a coefficient value of 0.912 . This value show that our sample is suitable for factor analysis. By applying the Bartlett test, the chi-square value was calculated to be $2419.249(p<0.000)$. According to these outcomes, it could be said that the scale is suitable for factor analysis. Table 6 shows the details.

Table 6. Factor Analysis Results.

\begin{tabular}{cccc}
\hline Item No. & Dimension & Factor 1 & Factor 2 \\
\hline RCI-3 & Intrapersonal Religiosity & 0.910 & \\
RCI-2 & Intrapersonal Religiosity & 0.900 & \\
RCI-5 & Intrapersonal Religiosity & 0.873 & \\
RCI-1 & Intrapersonal Religiosity & 0.812 & \\
RCI-4 & Intrapersonal Religiosity & 0.783 & \\
RCI-6 & Intrapersonal Religiosity & 0.555 & 0.839 \\
RCI-9 & Interpersonal Religiosity & & 0.826 \\
RCI-7 & Interpersonal Religiosity & & 0.768 \\
RCI-10 & Interpersonal Religiosity & & 0.767 \\
RCI-8 & Interpersonal Religiosity & 5.480 & 1.802 \\
& Eigenvalue & 54.802 & 18.019 \\
& Percent of Variance & 54.802 & 72.821 \\
& Cumulative Percent & \\
\multicolumn{4}{c}{ Kaiser-Meyer-Olkin Measure of Sampling Adequacy: 0.912 } \\
\hline
\end{tabular}

As stated in Table 6, regarding the factor analysis, the two-factor solution explained $72.821 \%$ of the total variance. Factor 1 reflects Intrapersonal Religiosity and includes six items that explain 54.802\% of the total variance. Factor 2 is named as Interpersonal Religiosity and constitutes four items that account for $18.019 \%$ of the total variance of the items. 
A multiple linear regression model was used to analyze the impact of dimensions of religiosity (intrapersonal religiosity and interpersonal religiosity) on the ethics of tax evasion (see Table 7). The regression analysis in Model 3 produced an adjusted $R^{2}=0.1604, F(2,344)=36.900, p=0.000$. The results showed that taxpayers' both intrapersonal and interpersonal religiosity appeared to have an important impact on ethical attitudes toward tax evasion. Taxpayers' interpersonal religiosity with higher scores tended to report lower scores for the ethics of tax evasion. Furthermore, intrapersonal religiosity seemed to be the key factor that influenced taxpayers' positive attitude toward evading taxes.

Table 7. Regression Analysis of Model 3.

\begin{tabular}{|c|c|c|c|}
\hline \multirow[t]{2}{*}{ Independent Variable } & \multicolumn{3}{|c|}{ Dependent Variable: Ethics of Tax Evasion } \\
\hline & $\beta$ & $t$-Value & Sig. \\
\hline Intercept & 3.8933 & 114.71 & $0.000 * * *$ \\
\hline Intrapersonal Religiosity & 0.271 & 0.0343 & $0.000 * * *$ \\
\hline \multirow[t]{2}{*}{ Interpersonal Religiosity } & -0.111 & 0.0339 & $0.001 * *$ \\
\hline & \multicolumn{3}{|c|}{$\begin{array}{c}R^{2}=0.1651 \text { Adj. } R^{2}=0.1604 \\
F(2,344)=36.900, p=0.000 * * * \\
\text { Homoscedasticity } \\
\text { Breusch-Pagan test }=3.16, p=0.21\end{array}$} \\
\hline
\end{tabular}

\section{Conclusions}

This empirical study finds that there is an important relationship between both interpersonal and intrapersonal religiosity as well as views on the ethics of tax evasion. The research uncovered that various reasons used to justify tax evasion had been put forward by participants in similar circumstances with strong feelings against the government. This, however, cannot be construed as a conclusive finding to show that those who have deployed justifications throughout the 500 years and in different nations have done so. The strongest assertions to justify tax evasion appeared to be the ones that involve human rights abuses. On the other hand, the weakest justifications were those where the taxpayer benefited from the taxes paid or where the funds were spent intelligently, where the risk of getting caught was low, or where everybody else was doing it.

The relative strength of the various reasons that have been advanced to justify tax evasion over the years remain similar to the findings of other studies based on the McGee (2012a) survey instrument, although the ranking of the 18 arguments may differ slightly from survey to survey. The present study, however, differs in that it has aimed to seek the opinions of a wider segment of the population. Many (not all) of the McGee surveys gathered student opinions, which is a subset of the general population. Thus, the findings of the present survey may be seen as more representative of the general population.

This current research can be replicated and expanded in various ways. Interpersonal and intrapersonal religiosity has thus far been underexplored in the literature. For that reason alone, this topic is ripe for future study. The present study did not attempt to investigate whether differences may exist for some of the demographic variables, such as age, gender, education, or marital status. Some of the McGee studies have explored these variables as part of the various 18-statement surveys but exploring male and female differences or differences based on age, marital status, or education level have not been done in the areas of interpersonal and intrapersonal religiosity.

The present study explored the Turkish opinion. Turkey is more than 98 percent Muslim, mostly Sunni Muslim (Wikipedia 2020). The present study could be replicated in other Sunni Muslim countries as well as Shia Muslim countries and non-Muslim countries to see whether the results are similar or different. Several studies have examined religious differences of opinion on the ethics of tax evasion in general, often using the 18-statement survey, but that survey did not include religiosity questions. Thus, examining the religiosity of other religions, such as Christianity, Buddhism, and Hinduism, 
among others, might be fruitful. Prior research has found that differences of opinion exist between and among the various religions (Bose 2012; Cohn 1998, 2012; DeMoville 1998; Jalili 2012; McGee 2012a; Mohd Ali 2013; McGee and Benk 2019; Schansberg 1998; Smith and Kimball 1998; Tamari 1998; Worthington et al. 2003) when it comes to tax evasion, but religiosity has not been the focus, therefore largely underexplored. Indeed, it is quite possible that Baptist Christians would have different mean scores than Catholic Christians, for example, or that Buddhists would have different views than Hindus or Muslims.

Author Contributions: Conceptualization, R.W.M., S.B., T.B.; methodology, S.B. and B.Y.; software, B.Y.; validation, S.B., B.Y. and T.B.; formal analysis, B.Y.; investigation, S.B., T.B.; resources, R.W.M.; data curation, B.Y., S.B., T.B.; writing-original draft preparation, R.W.M, S.B.; writing-review and editing, R.W.M., S.B., T.B., B.Y.; visualization, S.B.; supervision, R.W.M.; project administration, R.W.M.; funding acquisition, R.W.M. All authors have read and agreed to the published version of the manuscript.

Funding: This research received no external funding.

Conflicts of Interest: The authors declare no conflict of interest.

\section{References and Notes}

Ahmad, Mushtaq. 1995. Business Ethics in Islam. Islamabad: The International Institute of Islamic Thought \& The International Institute of Islamic Economics.

Aljaaidi, Khaled Slamen Yaslam, Nor Aziah Abdul Manaf, and Stewart S. Karlinsky. 2011. Tax evasion as a crime: A survey of perception in Yemen. International Journal of Business and Management 6: 190-201. [CrossRef]

Alm, James, and Jorge Martinez-Vazquez. 2010. Tax Evasion in the Informal Sector and Tax Morale in LAC Countries. In Developing Alternative Frameworks for Explaining Tax Compliance. Edited by James Alm, Benno Torgler and Jorge Martinez-Vazquez. London and New York: Routledge, pp. 260-91.

Alm, James, and Benno Torgler. 2006. Cultural differences and tax morale in the United States and in Europe. Journal of Economic Psychology 27: 224-46. [CrossRef]

Alm, James, Betty Jackson, and Michael McKee. 1992. Institutional Uncertainty and Taxpayer Compliance. American Economic Review 82: 1018-26.

Alm, James, Jorge Martinez-Vazquez, and Benno Torgler. 2006. Russian attitudes toward paying taxes-Before, during and after the transition. International Journal of Social Economics 33: 832-57. [CrossRef]

Anderson, Gary M., and Robert D. Tollison. 1992. Morality and Monopoly: The Constitutional Political Economy of Religious Rules. CATO Journal 13: 373-91.

Benk, Serkan, Robert W. McGee, and Adriana M. Ross. 2009. An Empirical Study of Ethical Opinion in Turkey. Journal of Accounting, Ethics \& Public Policy 10: 83-99.

Benk, Serkan, Robert W. McGee, and Bahadir Yüzbaşi. 2015. How Religions Affect Attitudes toward Ethics of Tax Evasion? A Comparative and Demographic Analysis. Journal of the Study of Religions and Ideologies 14: 131-49.

Block, Walter E., and Christian Torsell. 2020. Libertarian Perspectives on the Ethics of Taxation. In Ethics in Taxation. Edited by Robert F. van Brederode. Singapore: Springer Nature, pp. 91-113.

Bose, Sanjoy. 2012. Hindu Ethical Considerations in Relation to Tax Evasion. In The Ethics of Tax Evasion: Perspectives in Theory and Practice. Edited by Robert W. McGee. New York: Springer, pp. 135-47.

Burton, Hughlene A., Stewart S. Karlinsky, and Cynthia Blanthorne. 2005. Perception of a white-collar crime: Tax evasion. The ATA Journal of Legal Tax Research 3: 35-48. [CrossRef]

Cebula, Richard J., and Yassaman Saadatmand. 2005. Income Tax Evasion Determinants: New Evidence. Journal of the American Academy of Business 7: 124-27.

Cohn, Gordon. 1998. The Jewish View on Paying Taxes. Journal of Accounting, Ethics \& Public Policy 1: 109-20.

Cohn, Gordon. 2012. The Traditional Jewish View of Paying Taxes. In The Ethics of Tax Evasion: Perspectives in Theory and Practice. Edited by Robert W. McGee. New York: Springer, pp. 149-58.

Collymore, Aidan. 2020a. The Ethics of Tax Evasion: Literature Review. Working Paper. April 30. Available online: https://papers.ssrn.com/sol3/papers.cfm?abstract_id=3589385 (accessed on 3 June 2020).

Collymore, Aidan. 2020b. The Ethics of Tax Evasion: A Study of Opinion in the United Kingdom. Journal of Accounting, Ethics \& Public Policy 21: 201-45. 
Crowe, Martin T. 1944. The Moral Obligation of Paying Just Taxes. Washington: Catholic University of America Studies in Sacred Theology No. 84.

DeMoville, Wig. 1998. The Ethics of Tax Evasion: A Baha'i Perspective. Journal of Accounting, Ethics E Public Policy 1: 356-68.

Goel, Puneeta, and Rupali Misra. 2020. It's not inter-religiosity but intra-religiosity that really matters in attitude towards business ethics. International Journal of Ethics and Systems 36: 167-84. [CrossRef]

Gronbacher, Gregory M. A. 1998. Taxation: Catholic Social Thought and Classical Liberalism. Journal of Accounting, Ethics \& Public Policy 1: 91-100.

Gupta, Ranjana. 2009. An Empirical Study of Demographics of Perceptions of Tax Evasion in New Zealand. Journal of Australian Taxation 12: 1-40.

Gupta, Ranjana, and Robert W. McGee. 2010. Study on Tax Evasion Perceptions in Australasia. Australian Tax Forum 25: 507-34.

Hull, Brooks B. 2000. Religion Still Matters. Journal of Economics 26: 35-48.

Hull, Brooks B., and Frederick Bold. 1989. Towards and Economic Theory of the Church. International Journal of Social Economics 16: 5-15. [CrossRef]

Jalili, Ali Reza. 2012. The Ethics of Tax Evasion: An Islamic Perspective. In The Ethics of Tax Evasion: Perspectives in Theory and Practice. Edited by Robert W. McGee. New York: Springer, pp. 167-99.

James, Simon, Robert W. McGee, Serkan Benk, and Tamer Budak. 2019. How Seriously do Taxpayers Regard Tax Evasion? A Survey of Opinion in England, Journal of Money Laundering Control 22: 563-75. [CrossRef]

Kandri, Emirjeta, and Agim Mamuti. 2019. Ethics of Tax Evasion: The Case of Albania. In Tax Evasion as a Crime: A Study of Perception in Selected Countries. Edited by Agim Mamuti. Mauritius: Lambert Academic Publishing, pp. 12-18.

Karlinsky, Stewart, Hughlene Burton, and Cindy Blanthorne. 2004. Perceptions of tax evasion as a crime. e-Journal of Tax Research 2: 226-40.

King, Martin Luther, Jr. 1963. Letter from the Birmingham Jail. April 16.

LeCard, S. E. 1869. Gousset, Theologie Morale I, p. 504, as quoted in Crowe (1944) at 59.

Lipford, Jody, Robert E. McCormick, and Robert D. Tollison. 1993. Preaching Matters. Journal of Economic Behavior and Organization 21: 235-50. [CrossRef]

Mamuti, Agim, Megi Ikonomi, and Robert McGee. 2019. Tax Evasion as a Crime: A Survey of Perception in Bosnia and Herzegovina. In Tax Evasion as a Crime: A Study of Perception in Selected Countries. Edited by Agim Mamuti. Mauritius: Lambert Academic Publishing, pp. 19-29.

McGee, Robert W., ed. 2012a. The Ethics of Tax Evasion: Perspectives in Theory and Practice. New York: Springer.

McGee Robert, W. 2012b. The Ethics of Tax Evasion in Islam: A Comment. In The Ethics of Tax Evasion. Edited by Robert W. McGee. New York: Springer.

McGee, Robert W., and Serkan Benk. 2019. Christian Views toward Ethics of Tax Evasion: A Case Study. Journal of Financial Crime 26: 74-94. [CrossRef]

McGee, Robert W., and Zhiwen Guo. 2007. A Survey of Law, Business and Philosophy Students in China on the Ethics of Tax Evasion. Society and Business Review 2: 299-315. [CrossRef]

McGee, Robert W., and Tatyana B. Maranjyan. 2008. Opinions on Tax Evasion in Armenia. In Taxation and Public Finance in Transition and Developing Economies. Edited by Robert W. McGee. New York: Springer, pp. 277-307.

McGee, Robert W., and Sheldon R. Smith. 2007. Ethics and Tax Evasion: A Comparative Study of Accounting and Business Student Opinion in Utah. Paper presented at American Society of Business and Behavioral Sciences, 14th Annual Meeting, Las Vegas, NV, USA, February 22-25; vol. 14, pp. 1175-85.

McGee, Robert W., Jaan Alver, and Lehte Alver. 2008. The Ethics of Tax Evasion: A Survey of Estonian Opinion. In Taxation and Public Finance in Transition and Developing Economies. Edited by Robert W. McGee. New York: Springer, pp. 461-80.

McGee, Robert W., Serkan Benk, Halil Yıldırım, and Murat Kayıkcı. 2011. The Ethics of Tax Evasion: A Study of Turkish Tax Practitioner Opinion. European Journal of Social Sciences 18: 468-80.

McGee, Robert W., Jaan Alver, and Lehte Alver. 2012a. Tax Evasion Opinion in Estonia. In The Ethics of Tax Evasion: Perspectives in Theory and Practice. Edited by Robert W. McGee. New York: Springer, pp. 285-99.

McGee, Robert W., Yanira Petrides, and Adriana M. Ross. 2012b. How Serious Is Tax Evasion? A Survey of Mexican Opinion. In The Ethics of Tax Evasion. New York: Springer, pp. 405-11. 
Mohd Ali, Nor Raihana. 2013. The Influence of Religiosity on Tax Compliance in MALAYSIA. Ph.D. dissertation, Curtin University, Perth, Australia.

Morales, Alfonso. 1998. Income Tax Compliance and Alternative Views of Ethics and Human Nature. Journal of Accounting, Ethics \& Public Policy 1: 380-99.

Pennock, Robert T. 1998. Death and Taxes: On the Justice of Conscientious War Tax Resistance. Journal of Accounting, Ethics \& Public Policy 1: 58-76.

Schansberg, D. Eric. 1998. The Ethics of Tax Evasion within Biblical Christianity: Are There Limits to "Rendering unto Caesar"? Journal of Accounting, Ethics \& Public Policy 1: 77-90.

Slemrod, Joel B. 1985. An Empirical Test for Tax Evasion. Review of Economics and Statistics 67: 232-67. [CrossRef]

Smith, Sheldon R., and Kevin C. Kimball. 1998. Tax Evasion and Ethics: A Perspective from Members of The Church of Jesus Christ of Latter-Day Saints. Journal of Accounting, Ethics \& Public Policy 1: 337-48.

Spooner, Lysander. 1870. No Treason: The Constitution of No Authority, originally self-published by Spooner in Boston in 1870, reprinted by Rampart College in 1965, 1966 and 1971, and by Ralph Myles Publisher, Colorado Springs, CO in 1973.

Tamari, Meir. 1998. Ethical Issues in Tax Evasion: A Jewish Perspective. Journal of Accounting, Ethics E Public Policy 1: 121-32.

Thoreau, Henry David. 1849. Civil Disobedience. Ann Arbor: University of Michigan.

Torgler, Benno. 2007. Tax Compliance and Tax Morale: A Theoretical and Empirical Analysis. Cheltenham and Northampton: Edward Elgar.

Torgler, Benno. 2012. Attitudes toward Paying Taxes in the USA: An Empirical Analysis. In The Ethics of Tax Evasion: Perspectives in Theory and Practice. Edited by Robert W. McGee. New York: Springer, pp. 269-83.

Wikipedia. 2020. Islam by Country. Examined June 1. Available online: https://en.wikipedia.org/wiki/Islam_by_ country (accessed on 1 June 2020).

Worthington, Everett L., Jr., Nathaniel G. Wade, Terry L. Hight, Jennifer S. Ripley, Michael E. McCullough, James W. Berry, and Lynn O'Connor. 2003. The Religious Commitment Inventory-10: Development, refinement, and validation of a brief scale for research and counseling. Journal of Counseling Psychology 50: 84. [CrossRef] Yusuf, Sayyid Muhammad. 1971. Economic Justice in Islam. Lahore: Sh. Muhammad Ashraf.

(C) 2020 by the authors. Licensee MDPI, Basel, Switzerland. This article is an open access article distributed under the terms and conditions of the Creative Commons Attribution (CC BY) license (http://creativecommons.org/licenses/by/4.0/). 